\title{
International Journal of Instruction
}

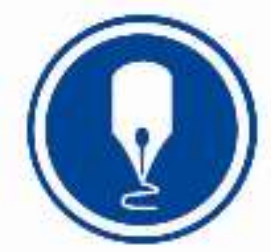

\author{
Abstracting / Indexing \\ ESCI - Emerging Sources Citation Index \\ ERIC - Education Resources Information Center

\section{Scopus} \\ EBSCO: \\ The Belt and Road Initiative Reference Source \\ Education Research Complete \\ Education Source \\ Index Copernicus ${ }^{\mathrm{TM}}$ \\ Cabell's Directory \\ DOAJ - Directory of Open Access Journals \\ Academic Journals Database \\ EdNA Online Database \\ ERA - Educational Research Abstracts Online \\ Electronic Journals Library \\ Genamics JournalSeek \\ Ulrich's Periodicals Directory
}

Note: International Journal of Instruction has a wide range of abstracting/indexing services. However, the index services have the right of one-sided termination of the contracts and not to publish any of the articles. Therefore, we do not accept any responsibilities caused by indexing problems. 
International Journal of Instruction e-ISSN: 1308-1470 • www.e-iji.net
July $2020 \bullet$ Vol.13, No.3

p-ISSN: 1694-609X

$\begin{array}{ll}\text { Editor in Chief } & \text { Managing Editor } \\ \text { Prof. Asım Arı } & \text { Dr. Gökhan Kayır }\end{array}$

Eskisehir Osmangazi University TURKEY

Dr. Kerim Sarıgül

Assistant Editors

Yunus Emre Institute

\begin{tabular}{l|l}
\hline Editorial Assistant & Technical Assistant \\
Dr. Rza Mammadov & Dr. Zehra Sümeyye Ertem \\
Dr. Eren Akdağ Kurnaz & Dr. Özgür Sirem \\
Dumlupınar University, TURKEY & $M E B$, TURKEY \\
\hline
\end{tabular}

Dumlupinar University, TURKEY Editors

Prof. Yousif A. Alshumaimeri

King Saud University, SAUDI ARABIA,

Prof. Luis E. Anido Rifon

University of Vigo, SPAIN

Prof. Trevor Bond

James Cook University, AUSTRALIA

Prof. Bronwen Cowie

University of Waikato, NEW ZEALAND

Prof. Do Coyle

The University of Edinburgh, UK

Prof. Angelique Dimitracopoulou

University of the Aegean, GREECE

Prof. William J. Fraser

University of Pretoria, SOUTH AFRICA

Assoc. Prof. Sheng-Wen Hsieh

Far East University, TAIWAN

Prof. Jennifer L. Jolly

University of Alabama, USA

Prof. Piet Kommers

University of Twente, NETHERLANDS

Prof. Christoph Randler

University of Tübinge, GERMANY

Prof. Elsebeth Korsgaard Sorensen University of Aarhus, DENMARK

Prof. Ken Stevens

Memorial University of Newfounland, CANADA

Prof. Selehattin Turan

Uludağ University, TURKEY

Prof. Thomas Gabriel

University of Zurich, SWITZERLAND

Language Editorial Board

Burcu Karafil - English

Yalova University, TURKEY

Contact Details: http://www.e-iji.net

E-mail: iji@ogu.edu.tr

editor.eiji@gmail.com

The authors are responsible for the errors, if any, in their published articles. 
International Journal of Instruction e-ISSN: 1308-1470 • www.e-iji.net
July $2020 \bullet$ Vol.13, No.3

p-ISSN: 1694-609X

\section{Advisory Board}

Assoc. Prof. Fasasi Yunus Adebunmi, NIGERIA Asst. Prof. Rula Khzouz, JORDAN

Asst. Prof. Abdelrahman Mohamed Ahmed,OMAN Prof. Abdurrahman Kılıç, TURKEY

Assoc. Prof. Orhan Akınoğlu, TURKEY

Dr. Mohammad Akram, SAUDI ARABIA

Assoc. Prof. Nor A. Alias , MALAYSIA

Prof. Akmatali Alimbekov, KYRGYZSTAN

Assoc. Prof. Ali Al-Issa, OMAN

Prof. Khaled Al-Ajlounı, JORDAN

Asst. Prof. Hussain Alkharusi, OMAN

Prof. Isela Almaguer, USA

Assoc. Prof Abdu Mohammed Al-Mekhlaf OMAN Assoc. Prof Manuel Lucero, SPAIN

Prof. Waleed K. A. Ahmed Alzand, KUWAIT

Prof. Abdullah Ambusaidi, OMAN

Prof. Neil J. Anderson, USA

Assoc. Prof. Derek L. Anderson, USA

Prof. Joel B. Babalola, NIGERIA

Assoc. Prof. Evangelos Bebetsos, GREECE

Assoc. Prof. Santosh Kumar Behera, INDIA

Assoc. Prof. Thalia Bellali, GREECE

Assoc. Prof. Mary Jo Garcia Biggs, USA

Prof. Larry Boles, USA

Prof. Dele Braimoh, SOUTH AFRICA

Prof. Robert Burden, UNITED KINGDOM

Prof. Marilyn Campbell, AUSTRALIA

Assoc. Prof. G. Nathan Carnes, USA

Dr. Carmencita L. Castolo, PHILIPPINES

Assoc. Prof. Yong-Fu Chang, TAIWAN

Dr. Lockias Chitanana, ZIMBABWE

Prof. Che Kum Clement, BANGLADESH

Prof. Dale Cook, USA

Prof. Valentina Dagiene, LITHUANIA

Assoc. Prof. Patrick Alan Danaher, AUSTRALIA

Asst. Prof. Jagannath K. Dange, INDIA
Prof. Remzi Y. Kıncal, TURKEY

Prof. Val Klenowski, AUSTRALIA

Asst. Prof. Yee Lai Kelly KU, HONG KONG

Prof. Colin Lankshear, AUSTRALIA

Prof. Kar-Tin Lee, AUSTRALIA

Assoc. Prof. Hsin-Chih Lin, TAIWAN

Dr. Hussain Ahmed Liton, SAUDI ARABIA

Assoc. Prof. Feng-Jung Liu, TAIWAN

Assoc. Prof. Zdena Lustigova, CZECH REPUBLIC

Prof. Ian Macdonald, AUSTRALIA

Prof. Lazarus Ndiku Makewa, KENYA

Asst. Prof. MD. Saiful Malak, BANGLADESH

Prof. Robin D. Mason, UNITED KINGDOM

Assoc. Prof. Mark A. Minott, CAYMAN ISLANDS

Dr. Norma T. Nemeh, JORDAN

Prof. Nel Noddings, USA

Prof. Yngve Troye Nordkvelle, NORWAY

Ngboawaji Daniel Nte, NIGERIA

Eylem Oruç, TURKEY

Prof. M. Çağatay Özdemir, TURKEY

Dr. Deborah Osberg, UNITED KINGDOM

Serkan Padem, TURKEY

Prof. Santosh Panda, INDIA

Prof. Hitendra Pillay, AUSTRALIA

Prof. Reza Pishghadam, IRAN

Prof. Ken Purnell, AUSTRALIA

Prof. Christoph Randler, GERMANY

Prof. Norman Reid, UNITED KINGDOM

Dr. Heri Retnawati, INDONESIA

Prof. Sushanta Kumar Roul, INDIA 
International Journal of Instruction e-ISSN: 1308-1470 • www.e-iji.net

Asst. Prof. Şahin Danişman, TURKEY

Asst. Prof. Ajay Das, USA

Prof. Estella De Los Santos, USA

Asst. Prof. İbrahim Delen, TURKEY

Prof. Ugur Demiray, TURKEY

Assoc. Prof. Esra Dereli, TURKEY

Assoc. Prof. Yannis Dimitriadis, SPAIN

Asst. Prof. Goulimaris Dimitris, GREECE

Asst. Prof. Mohamed Elsaadani, EGYPT

Prof. Noriko Fujioka-Ito, $A B D$

Prof. M. Jayne Fleener, USA

Assoc. Prof. Kristin A. Gansle, USA

Assoc. Prof. Lynn Kelting-Gibson, USA

Prof. Margarita Victoria Gomez, BRAZIL

Prof. Lena Green, SOUTH AFRICA

Asst. Prof. Semra GÜNGÖR, TURKEY

Prof. Carol Hall, UNITED KINGDOM

Prof. Amani Hamdan, SAUDI ARABIA

Assoc. Prof. Jace Hargis, USA

Asst. Prof. Seyed Ahmad Hashemi, IRAN

Dr. Mark van't Hooft, USA

Dr. Ghazi Adib Mustafa Husnieh, JORDAN

Asst. Prof. Irshad Hussain, PAKISTAN

Jaya Nur Iman, INDONESIA

Prof. Majed Abu Jaber, JORDAN

Assoc. Prof. Jason D. Johnson, UAE

Asst. Prof. Troy Jones, USA

Prof. William E. Doll, Jr., USA

Norma A. Juarez Collazo, BELGIUM

Prof. Gregory J. Kelly, USA

Assoc. Prof. Shahadat Hossain Khan, BANGLADESH Asst. Prof. Muhammad Imran Yousuf, PAKISTAN

Prof. Abdalla Mohamed Khataybehi, JORDAN

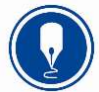

July $2020 \bullet$ Vol.13, No.3

p-ISSN: 1694-609X

Prof. Peter A. Rubba, USA

Prof. Despina Sapountzi-Krepia, CYPRUS

Prof. Barbara Seidemann, SWITZERLAND

Assoc. Prof. Yilfashewa Seyoum, ETHIOPIA

Dr. Afsaneh Sharif, CANADA

Nazia Sharif, PAKISTAN

Prof. Ramesh Chander Sharma, INDIA

Asst. Prof. Laurie A. Sharp, USA

Prof. Ju-Ling Shih, TAIWAN

Asst. Prof. Mahesh B. Shinde, INDIA

Assoc. Prof. Hosin Shirvani, $A B D$

Assoc. Prof. Harison Mohd Sidek, MALAYSIA

Assoc. Prof. Parlindungan Sinaga, INDONESIA

Assoc. Prof. Richard B. Speaker, Jr., USA

Prof. N. Suzanne Standerford, USA

Prof. Howard Stevenson, UNITED KINGDOM

Dr. Simon Stobart, UNITED KINGDOM

Assoc. Prof. Pei-Chen Sun, TAIWAN

Prof. Karen Swan, USA

Prof. Jim Taylor, AUSTRALIA

Prof. Siew Ming Thang, MALAYSIA

Prof. Y. Gürcan Ültanir, TURKEY

Dr. Muhammad A. Wahid Usmani, SAUDI ARABIA

Prof. Erwin Wagner, GERMANY

Assoc. Prof. Michael Whitacre, USA

Asst. Prof. Julia Wilkins, USA

Dr. Kung Teck Wong, MALAYSIA

Asst. Prof. Chia Jung Yeh, USA

Prof. Ali Yildirim, TURKEY

Prof. Allan E. Young, CAYMAN ISLANDS

Dr. Yunisrina Qismullah Yusuf, INDONESIA

Prof. Galip Yüksel, TURKEY

Assoc. Prof. Eleni Zetou, GREECE 


\section{Contents}

From the Editor: Research into Technology Enhanced Learning: Do we Really Need a Control Group?

Eric Sanchez i-iv

Knowledge Sharing Behavior in the Curricula of United Arab Emirates Universities and Educational Organizations

Hani Yousef Jarrah, Mohammad Salman Alkhazaleh.

Development of Smartphone App as Media to Learn Impulse-Momentum Topics for High School Students

Johannes VD Wirjawan, Daniel Pratama, Elisabeth Pratidhina, Anthony Wijaya, Budijanto

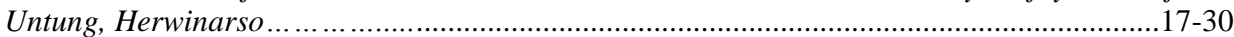

Innovative Organization's Components in Basic Education Institutions in Thailand

Aniruth Boonkua, Ampapan Tuntinakorngul, Pariyaporn Tungkunanan.

Instructional Methods and Self-Regulated Learning in Writing

Mutiarani Pionera, I Nyoman Sudana Degeng, Utami Widiati, Punaji Setyosari..

Causes and Effects of the Division Algorithm Applied in Ecuadorian Education

Mendoza Velazco Derling José, Cejas Martínez Magda Francisca, Navarro Cejas Mercedes, Flores Hinostroza Elizeth Mayrene, Vega Falcón Vladimir. 61-74

Guided Discovery Problem-Posing: An Attempt to Improve Science Process Skills in Elementary School

Suryanti, Wahono Widodo, Widowati Budijastuti......

Preparing for Industry 4.0 - Will youths have enough essential skills?: An Evidence from Thailand

Wilert Puriwat, Suchart Tripopsakul. $89-104$

New Language Learning Environment: Employers' - Learners' Expectations and the Role of Teacher 4.0

Tatiana Peredrienko, Oxana Belkina, Elena Yaroslavova.

Why I'm Bored in Learning? Exploration of Students' Academic Motivation

Helga Graciani Hidajat, Fattah Hanurawan, Tutut Chusniyah, Hetti Rahmawati.

Beliefs and Classroom Assessment Practices of English Teachers in Primary Schools in Thailand Arthitaya Narathakoon, Sutthirak Sapsirin, Pramarn Subphadoongchone.

Validity and Practicality of the Biotechnology Series Learning Model to Concept Mastery and Scientific Creativity

Iwan Wicaksono, Supeno, Aris Singgih Budiarso.

Comparison between Group Discussion Flipped Classroom and Lecture on Student Achievement and Student Characters

Putu Sudarmika, I Wayan Santyasa, Dewa Gede Hendra Divayana......

The Effect of a Dual Coding Technique on Idiom Interpretation in ESL/EFL Learners

Denis Samburskiy

Unplugged Coding Using Flowblocks for Promoting Computational Thinking and Programming among Secondary School Students

Arinchaya Threekunprapa, Pratchayapong Yasri... 
The Effect of Parenting Patterns and Empathy Behavior on Youth Prosocial Syahril, Syamsu Yusuf, Ilfiandra, Sofwan Adiputra. $.223-232$

Effectiveness of Environmentally-Based Science Learning towards Environmentally-Friendly Character of Students in Coastal Area

Elya Nusantari, Ramli Utina, Abubakar Sidik Katili, Yowan Tamu, Insar Damopolii.

$233-246$

The Impact of Englishgame-Based Mobile Application on Students' Reading Achievement and Learning Motivation

Nina Sofiana, Husni Mubarok.

Improving Social Skills through Structured Playfulness Program in Preschool Children Marina Tersi, Ourania Matsouka..

Effect of Concept Attainment Models and Self-Directed Learning (SDL) on Mathematics Learning Outcomes

Moch. Sukardjo, Mohamad Salam.

Effectiveness of Disney's NLP-based Strategy to Improve Student's Higher Order Thinking Skills Mohamad Tahar Mohamad Amirnudin, Salmiza Saleh. 293-306

The Correlation of Scientific Knowledge-Science Process Skills and Scientific Creativity in Creative Responsibility Based Learning

Zainuddin, Suyidno, Dewi Dewantara, Saiyidah Mahtari, Mohamad Nur, Leny Yuanita, Titin Sunarti... $.307-316$

Measuring the Importance of Non-Technical Skills for Integration into Metalwork Technology Curriculum Using Structural Equation Modelling

Bakare Shola Francis, Azlan Abdul Latib, Evarina Amiron, Kamalularifin Subari, Yusri Kamin. 317-328

Effectiveness of CEL-Badis Learning Model on Students' Creative-Thinking Skills: Case on the Topic of Simple Food Biotechnology

Idam Ragil Widianto Atmojo, Sajidan

The Effectiveness of Mobile Augmented Reality Assisted STEM-Based Learning on Scientific Literacy and Students' Achievement

Yuliana Wahyu, I Wayan Suastra, I Wayan Sadia, Ni Ketut Suarni 343-356

Does the Teaching and Learning Process in Primary Schools Correspond to the Characteristics of the 21 st Century Learning?

Lalu Sumardi, Arif Rohman, Dwi Wahyudiati...... $357-370$

The Analysis of Using Active Learning Technology in Institutions of Secondary Vocational Education

Tatyana Nikolaevna Bochkareva, Elvir Munirovich Akhmetshin, Angelina Olegovna Zekiy, Arkadiy Viktorovich Moiseev, Margarita Evgenevna Belomestnova, Irina Aleksandrovna Savelyeva, Olga Sergeevna Aleynikova .......................................................................371-386

Implementing Immediate Feedback with Unlimited Plus Bonus Points to Increase College Student Learning Motivation and Achievement

Riyanto, Diah Aryulina $387-400$

The Development of Student Motivation to Learn English at a University in Mexico Peter Reilly $.401-416$ 
Computer- vs. Mobile-Assisted Learning to Promote EFL Students' Speaking Skills: A Preliminary Classroom-Based Research

Yudi Juniardi, Lina Herlina, Arif Husein Lubis, Irmawanty, John Pahamzah.. $417-432$

Instructional Materials for Discovery Learning with Cognitive Conflict Approach to Improve Vocational Students' Achievement

Gunawan, Kosim, P. Ayu Suci Lestari

Insights from Saudi Student Teachers: Successes and Challenges

Hiya Almazroa.

The Effect of Van Hiele Learning Model on Students' Spatial Abilities

I Gusti Ngurah Pujawan, I Putu Pasek Suryawan, Dewa Ayu Ari Prabawati..

Evaluation of the Teachers' Acceptance to E-Report Card Applications with the Hot-Fit Model Approach

Ketut Agustini, I Gede Mahendra Darmawiguna, I Kadek Dwi Artayasa, I Nengah Eka Mertayasa

Students' Competence in Cognitive Process and Knowledge in Biology Based on Curriculum Used in Indonesia

Paidi Paidi, Ixora Sartika Mercuriani, Bambang Subali. $.491-510$

A Longitudinal Study for the Relationship between Motor Coordination and Body Mass Index in Primary School Children

Dimitra Doloma, Antonios Kambas, Nikolaos Aggeloussis, Maria Michalopoulou $.511-524$

The Effectiveness of Collaborative Creativity Learning Models (CCL) on Secondary Schools Scientific Creativity Skills

Sri Astutik, Endang Susantini, Madlazim, Mohamad Nur, Supeno... $.525-538$

Development of an Instructional Model with Augmented Reality Technology for Vocational Certificate Students

Theeraphant Pipattanasuk, Alisa Songsriwittaya $539-554$

Effectiveness of Process Oriented Guided Inquiry Learning with Peer Feedback on Achieving Students' Mathematical Reasoning Capabilities

Kartono, Rena Yuliantika Shora.

Values of Tolerance in Relation to Academic Achievements, Cultures, and Gender among UAE Universities Students

Salwa AlMajali, Khalid AlKhaaldi.

Authentic Assessment for Speaking Skills: Problem and Solution for English Secondary School Teachers in Indonesia

M. Zaim, Refnaldi, Safnil Arsyad. $.587-604$

Using the Mother Tongue in Foreign-Language Learning: Secondary School Students in Kazakhstan

Lyazzat Beisenbayeva..... $.605-616$

Empirical Analysis of Diagramatic Representation Test Instruments Using Partial Credit Model in Realizing Learning Outcomes

Warsono, Puji Iman Nursuhud, Rio Sandhika Darma, Supahar. $.617-632$ 
Mathematical Instructional: A Conceptual of Redesign of Active Learning with Metacognitive Regulation Strategy

Mohamad Ariffin Abu Bakar, Norulhuda Ismail. $.633-648$

Applying Self-Regulated Learning Intervention to Enhance Students' Learning: A QuasiExperimental Approach

Astri Dwi Jayanti Suhandoko, Chi-Sui Hsu.

Learning Model of Undergraduate Students: Confirmatory Factor Analysis

Pariyaporn Tungkunanan...

Design of Blended Learning Based on Tri Kaya Parisudha Using Kelase Platform in Realizing Hybrid-Superitem Learning in Mathematics Lessons

I Putu Wisna Ariawan, Dewa Gede Hendra Divayana

The Effects of the Synchronous Discussion and Reflection System (SDRS) In Perception of Knowledge Building and Learning Outcomes

Cinthya Indrastyawati, Ying-Tien Wu, Sugito

Embracing Industrial Revolution 4.0: The Effect of Using Web 2.0 Tools on Primary Schools Students' Mathematics Achievement (Fraction)

Nurulwahida Azid, Rozita Hasan, Nurul Fazilah Mohamad Nazarudin, Ruzlan Md-Ali....711-728

Comparison between Generative Learning and Discovery Learning in Improving Written Mathematical Communication Ability

Wardono, Rochmad, Khasanah Uswatun, Scolastika Mariani

Indirect Specialized Vocabulary Learning and Learner Autonomy

Elham Ghobain

The Flipped Pedagogy: Effects on the Grammatical Competence and Writing Skill of Basic Users of English

Mohammadreza Valizadeh, Fatemeh Soltanpour.

$761-776$

The Creation of Teaching Aids for Disabled Students as Mathematical-Thinking-Imaginative Product

Sugiman, Hardi Suyitno, Iwan Junaedi, Dwijanto.....

The Effects of Reading-While-Listening and Listening-Before-Reading-While-Listening on Listening and Vocabulary

Boonyarit Tangkakarn, Chanika Gampper. $.789-804$

Learning Decision and Spiritual Based Skills for Adult Education

Elfi Mu'awanah, Nur Hidayah, Sulistyorini, Rifa Hidayah.

Teacher's Engagement in the Social and Emotional Guidance of Elementary School Students Jessie Koh-Sing Tnay, Shahren Ahmad Zaidi Adruce, Evan Lau, Hiram Ting, Chuo Yew Ting, Mukvinder Kaur Sandhu. $.827-844$

Determinants of Teacher Performance with Job Satisfactions Mediation

Arief Tukiman Hendrawijaya, Muhammad Irfan Hilmi, Fuad Hasan, Niswatul Imsiyah, Deditiani Tri Indrianti.... $845-860$

Effects of Students' Motivation and Engagement on Students' Satisfaction in a Lecture: Empirical Analysis 
International Journal of Instruction e-ISSN: 1308-1470 • www.e-iji.net

The Use of Experiential Learning as a Teaching Strategy in Life Sciences

Genevieve Mc Pherson-Geyser, Rian de Villiers, Portia Kavai.

Developing Innovative Chemistry Laboratory Workbook Integrated with Project-based Learning and Character-based Chemistry

Bajoka Nainggolan, Wesly Hutabarat, Manihar Situmorang, Marham Sitorus..... $.895-908$

The Power of Openness to Experience, Extraversion, L2 Self-confidence, Classroom Environment in Predicting L2 Willingness to Communicate

Irum Fatima, Shaik Abdul Malik Mohamed Ismail, Zahid Hussain Pathan, Ubedullah

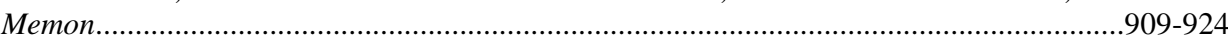

